\title{
Przemiany krajobrazu doliny Luciąży i jej otoczenia po utworzeniu zbiornika retencyjnego Cieszanowice
}

\section{Changes in the landscape of Luciąża valley and the surrounding areas after creating a storage reservoir in Cieszanowice}

\begin{abstract}
Zarys treści
W artykule przedstawiono przemiany krajobrazu jakie dokonały się w dolinie Luciąży $\mathrm{i}$ jej otoczeniu w związku z utworzeniem zbiornika retencyjnego Cieszanowice. Na podstawie pomiarów głębokości opracowano mapę batymetryczną zbiornika, zaznaczając na niej miejsca o ograniczonej dostępności z uwagi na obecność nymfeidów i roślinności szuwarowej. Na mapie tej wskazano również miejsca występowania w toni wodnej pni oraz gałęzi niewykarczowanych przed zalaniem krzewów, które stwarzają realne zagrożenie dla sprzętu pływającego. W artykule odniesiono się do rozbieżności pomiędzy planowanymi funkcjami zbiornika Cieszanowice a jego rzeczywistym użytkowaniem po dwudziestu latach istnienia. Na mapach użytkowania ziemi zilustrowano przemiany w pokryciu terenu, jakie dokonały się wraz z zanikiem funkcji rolniczych i rozwojem osadnictwa turystycznego połączonego $z$ intensywnym użytkowaniem rekreacyjnym.
\end{abstract}

Słowa kluczowe Zbiornik retencyjny, odłogi, osadnictwo turystyczne, mapa batymetryczna.

Abstract

The article presents landscape transformations which occurred in the Luciąża valley and the surrounding areas as a result of creating a storage reservoir in Cieszanowice. On the basis of depth measurements, a bathymetric map of the reservoir was prepared, on which locations of limited accessibility due to the presence of nympheids and reed and rush communities were marked. The map also shows the locations of tree trunks and branches of uncut bushes in the depths of the reservoir, which pose a real threat to water sports equipment. The article addresses the divergences between the planned functions of the Cieszanowice reservoir and its actual usage after twenty years of existence. Transformations of land cover which occurred along with the disappearance of agricultural functions and the growth of tourist settlement combined with intensive recreational use were illustrated in land use maps.

Keywords Storage reservoir, fallow lands, tourist settlement, bathymetric map.

\section{Wprowadzenie}

Budowa zbiorników retencyjnych, prowadzi do istotnych przemian w strukturze i funkcjonowaniu systemu krajobrazowego doliny rzecznej. Poza aspektami hydrologicznymi i hydrogeologicznymi, wynikającymi ze spiętrzenia wód, odrębną grupę zagadnień stanowią zmiany krajobrazowe związane z użytkowaniem terenów wokół akwenów. $\mathrm{W}$ artykule przedstawiono przemiany krajobrazu jakie nastąpiły $w$ dolinie Luciąży i jej otoczeniu po powstaniu zbiornika Cieszanowice.

\section{Cele i metody badań}

Celem artykułu jest przedstawienie zbiornika retencyjnego Cieszanowice na Luciąży, jego planowanych i realizowanych funkcji, batymetrii, walorów rekreacyjnych, a także przemian w strukturze użytkowania ziemi w otoczeniu akwenu po dwudziestu latach jego funkcjonowania.

W celu uzyskania szczegółowszej informacji o warunkach batymetrycznych akwenu, przeprowadzono sondowanie dna zbiornika w dniach 24 i 25 sierpnia 2017 roku, uzupełnione dodatkowymi pomiarami z 13 i 16 września 2018 roku. Sondowanie prowadzono z łodzi za pomocą stalowego, płaskodennego obciążnika o wadze $1 \mathrm{~kg}$, zawieszonego na taśmie mierniczej. Na podstawie 360 pomiarów głębokości odniesionych do normalnego poziomu piętrzenia (NNP), wynoszącego 205,25 m n.p.m., wykonano mapę batymetryczną przy zastosowaniu programu ArcGis. Każdemu sondowaniu głębokości towarzyszył odczyt położenia uzyskany za pomocą urządzenia GPS GARMIN GPSMAP 62s. Dane pomiarowe głębokości zbiornika zapisano w formacie GPX.

W celu ukazania rozmiarów przemian został porównany obraz użytkowania tych terenów przed powstaniem zbiornika z aktualnym ich zagospodarowaniem. Do odtworzenia dawnego użytkowania wykorzystano zdjęcia lotnicze w skali 1:19000 wykonane 02.08.1973 roku, udostępnione przez Centralny Ośrodek Dokumentacji Geodezyjnej i Kartograficznej w Warszawie. Obecny obraz użytkowania powstał na podstawie kartowania terenowego, przeprowadzonego w 2018 roku z wykorzystaniem ortofotomapy ze strony www.geoportal.gov.pl. 


\section{Lokalizacja obszaru badań}

Luciąża, niewielka rzeka o długości 54,2 km, prowadzi swe wody przez obszar położony w strefie przejściowej między Wyżyną Małopolską a Nizinami Środkowopolskimi.
Według regionalizacji fizycznogeograficznej Polski w układzie dziesiętnym (Kondracki 2000), zmodyfikowanej przez Majchrowską i Papińską (2018), dorzecze Luciąży znajduje się na Wzgórzach Radomszczańskich (342.11) i Równinie Piotrkowskiej (318.83) (ryc. 1).

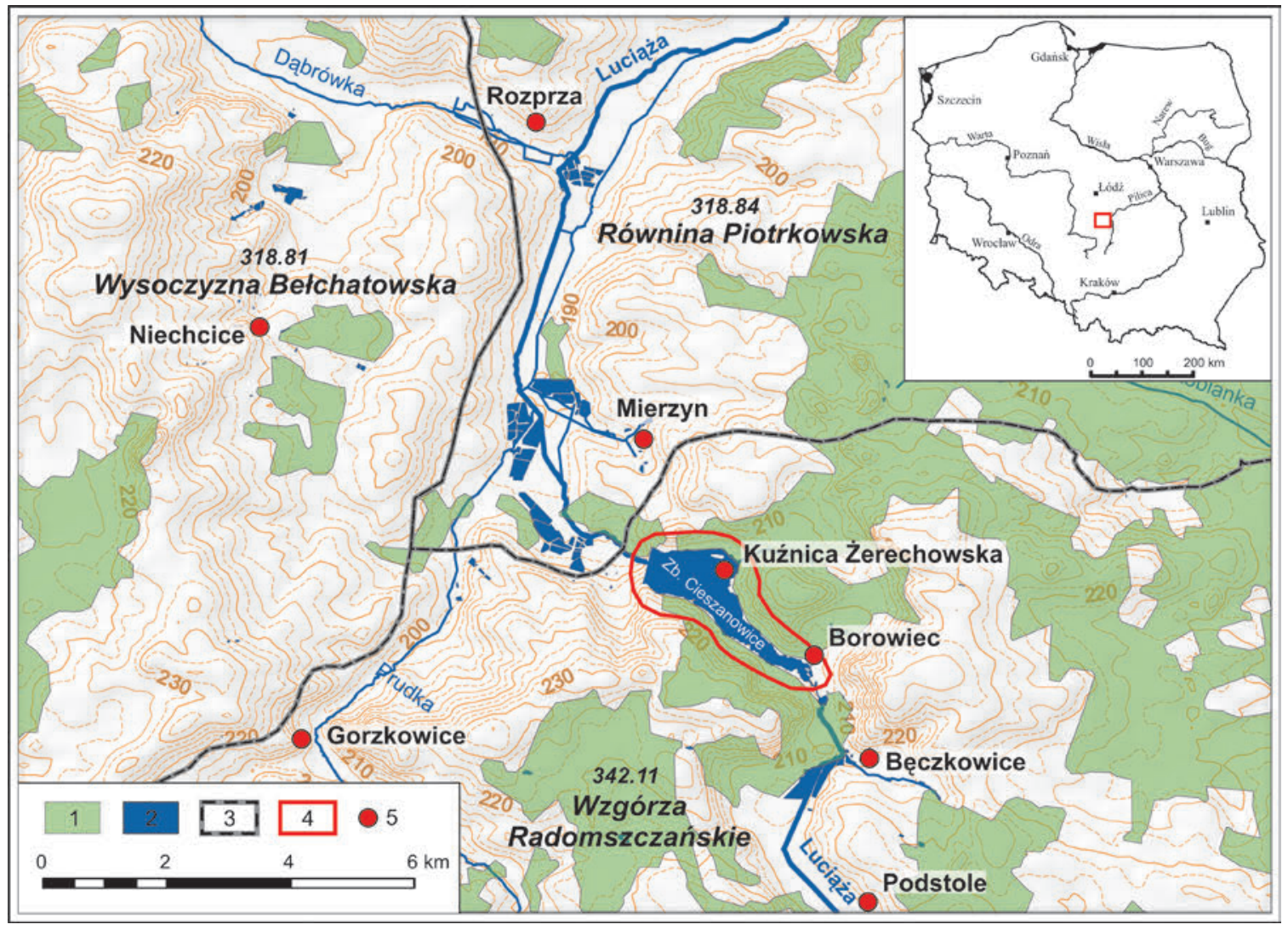

Ryc. 1. Położenie zbiornika Cieszanowice na tle jednostek fizycznogeograficznych według J. Kondrackiego (2000) w modyfikacji A. Majchrowskiej i E. Papińskiej (2018): 1 - lasy, 2 - wody powierzchniowe, 3 - granice mezoregionów, 4 - strefa brzegowa, 5 - miejscowości

Fig. 1. Location of the Cieszanowice reservoir in relation to physico-geographical units by J. Kondracki (2000), as modified by A. Majchrowska and E. Papińska (2018): 1 - forests, 2 - surface water, 3 - mesoregion boundaries, 4 - coastal zones, 5 - settlements

Wraz z biegiem Luciąży obserwujemy zmiany w morfologii i fizjonomii doliny. Na południe od zbiornika Cieszanowice, począwszy od Przerąbu przez Podstole, Bęczkowice po Trzepnicę, dno doliny jest szerokie, płaskie, silnie zatorfione, osiągając miejscami szerokość dwóch kilometrów. Obok zmeliorowanych terenów łąkowo-pastwiskowych występują tu podmokłe torfowiska z licznymi kępami zarośli wierzbowych, doły po eksploatacji torfu oraz duże kompleksy stawów hodowlanych. Siedliska w tym fragmencie doliny Luciąży posiadają dużą wartość przyrodniczą, co potwierdza objęcie ochroną powierzchni 191,2 ha w ramach obszaru Natura 2000 "Łąka w Bęczkowicach" (PLH 100004). Obszar ochronny obejmuje brzegi Luciąży, porastające je zarośla wierzbowe oraz ukształtowane na torfowiskach łąki, które do połowy lat 80 . XX wieku były koszone i wypasane.

Począwszy od Trzepnicy, aż po Cieszanowice dolina Luciąży ulega zwężeniu, a deniwelacje dochodzą do 40 metrów. Rzeka wkracza w odcinek przełomowy, w którym rozcięte zostały pagóry moren czołowych, będących częścią Wzgórz Dobryszyckich (Wachecka-Kotkowska 2004).
Szerokość doliny Luciąży w tej strefie wynosi od 300 do 700 metrów. Przewężenie w zachodniej części doliny, dochodzące do 500 metrów, wykorzystano do zlokalizowania tamy dla zbiornika Cieszanowice. Ponad dnem doliny silnie zarysowują się partie wysoczyznowe sięgające do 235 m n.p.m. (ryc. 2). Rzeźbę wysoczyzny dodatkowo urozmaicają pagóry wydmowe o wysokościach względnych od 2 do 8 metrów.

Poniżej Cieszanowic Luciąża wpływa na Równinę Piotrkowską, kierując się ku północy. Dolina na powrót staje się płaskodenna, osiągając szerokość od 1,5 do 2 kilometrów. W tej części doliny dominują użytki łąkowo-pastwiskowe, natomiast w okolicach Mierzyna gospodarka stawowa. Do czasu wybudowania zbiornika Cieszanowice, Luciążę cechowała duża zmienność stanów i przepływów wody. Dobowe wahania stanów wody w profilu Kłudzice osiągały $100 \mathrm{~cm}$, a w cyklu miesięcznym dochodziły do $266 \mathrm{~cm}$ (Gładysz 1985). Obecnie, pomimo funkcjonowania zbiornika retencyjnego, nadal niemal co roku, obserwuje się wiosenne wezbrania, podczas których Luciąża występuje z brzegów i rozlewa się na okolicznych łąkach (fot. 1). 


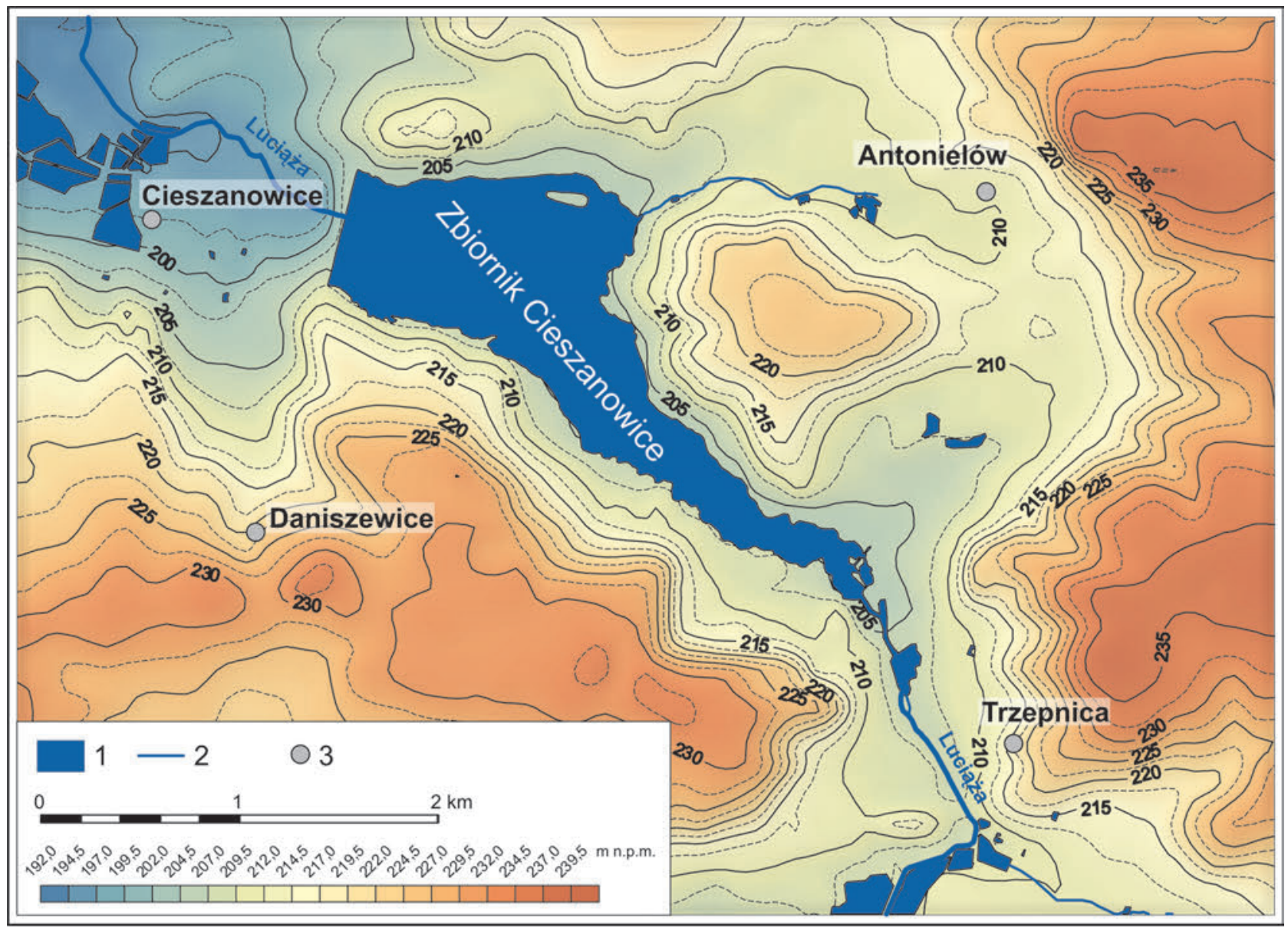

Ryc. 2. Rzeźba terenu okolic zbiornika Cieszanowice: 1 - zbiorniki rekreacyjne i stawy rybne, 2 - rzeki, 3 - miejscowości

Fig. 2. Relief of the area surrounding the Cieszanowice reservoir: 1 - storage reservoirs and fishponds, 2 - rivers, 3 - settlements

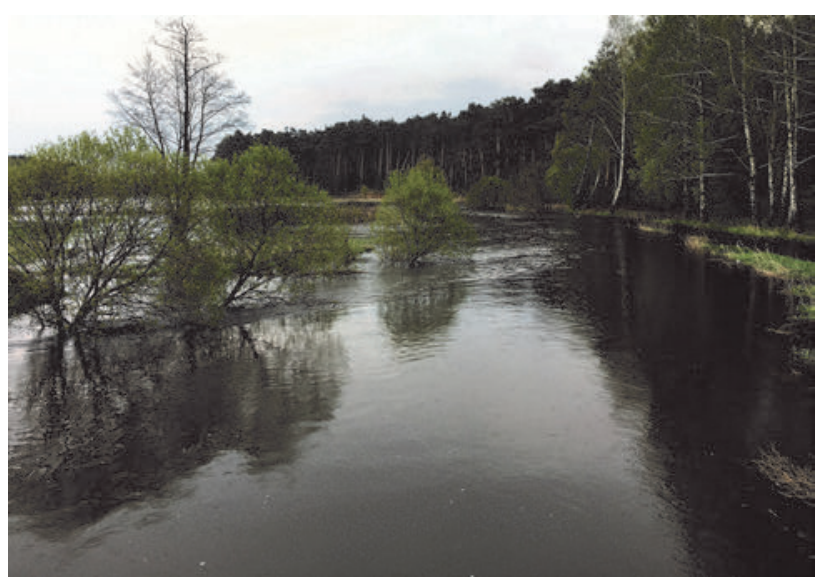

W opinii Gładysza (1976), powyższą sytuację warunkuje litologia serii powierzchniowych, zdominowanych przez występowanie utworów słabo i średnio przepuszczalnych. Zdaniem wspomnianego autora należy przypuszczać, „że w ogólnym obrazie badanego obszaru proces spływu wód powierzchniowych przeważa nad infiltracją, a głównym źródłem zasilania rzek w wodę są opady".
Fot. 1. Wiosenne wezbranie Luciąży w rejonie posterunku wodowskazowego Kłudzice. Widok z mostu w kierunku południowo-wschodnim (fot. M. Szymczyk, 29.04.2017)

Photo 1. Springtime flooding of the Luciąża river near the water gauging station in Kłudzice. View from the bridge towards the south-east (photo by M. Szymczyk, 29.04.2017)

\section{Przesłanki środowiskowe i gospodarcze budowy zbiornika retencyjnego}

Dolina Luciąży już w odległej przeszłości była terenem zamieszkiwanym i użytkowanym przez człowieka. Badania archeologiczne potwierdzają jej użytkowanie od epoki kamienia, przez epokę brązu, epokę żelaza, wczesne średniowiecze, aż po czasy nowożytne (Błaszczyk 2000). 
Od dawna do celów gospodarczych wykorzystuje się również energię spiętrzonych wód Luciąży. Z analiz kartograficznych Krzemińskiego i Nowakowskiego (1980) wynika, że w latach 20. XIX wieku na Luciąży istniały 32 urządzenia spiętrzające wodę, a rzeka napędzała 13 młynów. Na późniejszych mapach topograficznych tylko w rejonie przełomowego fragmentu doliny Luciąży, na odcinku o długości czterech kilometrów, są zaznaczone trzy młyny - Nowy Młyn w Trzepnicy, młyn Borowiec i młyn w Kuźnicy Żerechowskiej.

Postulat budowy kilku zbiorników retencyjnych w zlewni Luciąży, w tym jednego na samej Luciąży w pobliżu Bęczkowic, argumentował Gładysz (1976). Potrzebę budowy zbiorników uzasadniał małymi zdolnościami retencyjnymi obszaru, przewagą spływów powierzchniowych nad infiltracją, intensyfikacją produkcji rolnej, prognozowanym rozwojem leja depresyjnego Kopalni Węgla Brunatnego „Bełchatów” oraz deficytami wody w dorzeczu. W związku z budową i eksploatacją odkrywkową w kopalni „Bełchatów” zakładano, że lej depresyjny spowodowany odwadnianiem złoża doprowadzi do poważnych zmian w stosunkach wodnych. Przewidywano, że po roku 1980, gdy kopalnia „Bełchatów” osiągnie pełen rozwój, lej depresyjny obejmie zachodnią część dorzecza Pilicy, głównie zlewnię Luciąży (Gładysz 1981). Głównym celem budowy zbiornika miało być zniwelowanie wpływu deficytu wody

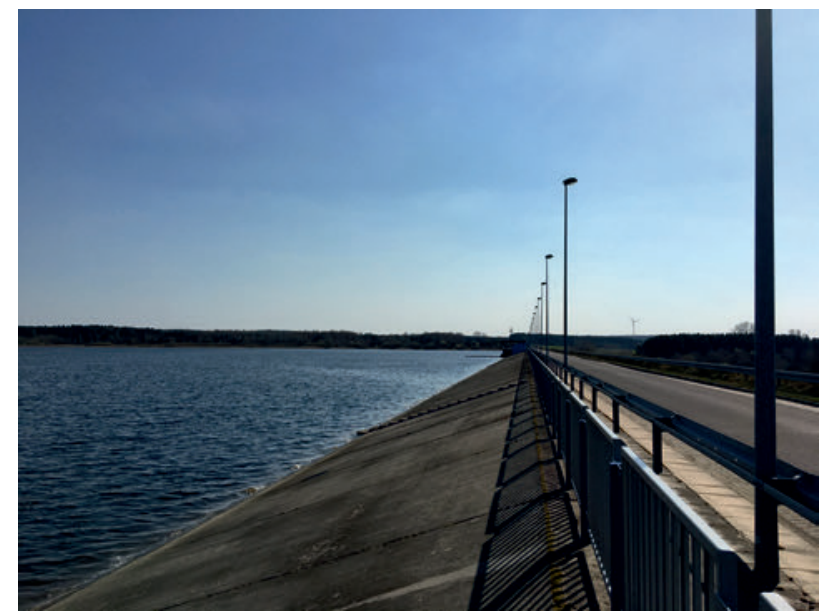

Fot. 2. Zapora czołowa (fot. M. Szymczyk, 01.04.2017)

Photo 2. Front dam (photo by M. Szymczyk, 01.04.2017)

\section{Zbiornik Cieszanowice - batymetria}

W dokumencie Ocena stanu technicznego i bezpieczeństwa zbiornika Cieszanowice (2001) podano, że średnia głębokość zalewu wynosi 3,2 m. Informacja o średniej głębokości daje jedynie ogólny obraz, natomiast brak jest informacji o przestrzennym rozkładzie głębokości.

Przeprowadzone pomiary głębokości pozwoliły stwierdzić, że są one największe przy odwodnej stronie zapory oraz w najszerszej części zbiornika (ryc. 3). Rozkład głębokości nawiązuje do spadków podłużnych zalanej doliny. Minima występują przy brzegach oraz w zwężającej się części zbiornika, aż do jego cofki. Maksymalna głębokość wynosi ok. 7 metrów. W trakcie badań zaobserwowano na gospodarkę rolną regionu, a także uzupełnienie zasobów zlewni Luciąży na obszarze obniżenia poziomu wód gruntowych w zasięgu leja depresyjnego. Najkorzystniejsze predyspozycje przyrodnicze do przegrodzenia doliny zaporą ziemną i uzyskania znacznej powierzchni piętrzenia, a także zminimalizowania obszaru podtopień, zapewniał jedynie przełomowy odcinek doliny Luciąży między Trzepnicą a Cieszanowicami.

Pierwszym etapem budowy zbiornika retencyjnego Cieszanowice było wysiedlenie mieszkańców wsi Kuźnica Żerechowska oraz rozebranie 21 zabudowań wraz z młynem. W kolejnych etapach przygotowywano podłoże pod zbiornik. Teren został wylesiony oraz usunięto pokrywę glebową wraz z częścią materiału organicznego znajdującego się na obrzeżach planowanego akwenu. Zbiornik powstał w 26. kilometrze biegu rzeki, dzięki spiętrzeniu wód Luciąży czołową zaporą ziemną o długości 849 metrów (fot. 2). Powierzchnia zlewni w przekroju zapory czołowej wynosi $105 \mathrm{~km}^{2}$. Napełnianie zbiornika rozpoczęto w lutym 1997 roku, a do eksploatacji oddano go w grudniu 1998 roku. Elementami zbiornika są również budowla przelewowo-upustowa z elektrownią wodną o mocy 45 kW oraz zapora boczna „Borowiec” o długości 520 m (fot. 3). Powierzchnia zbiornika przy maksymalnej rzędnej piętrzenia 260,00 m n.p.m. wynosi 260 hektarów.

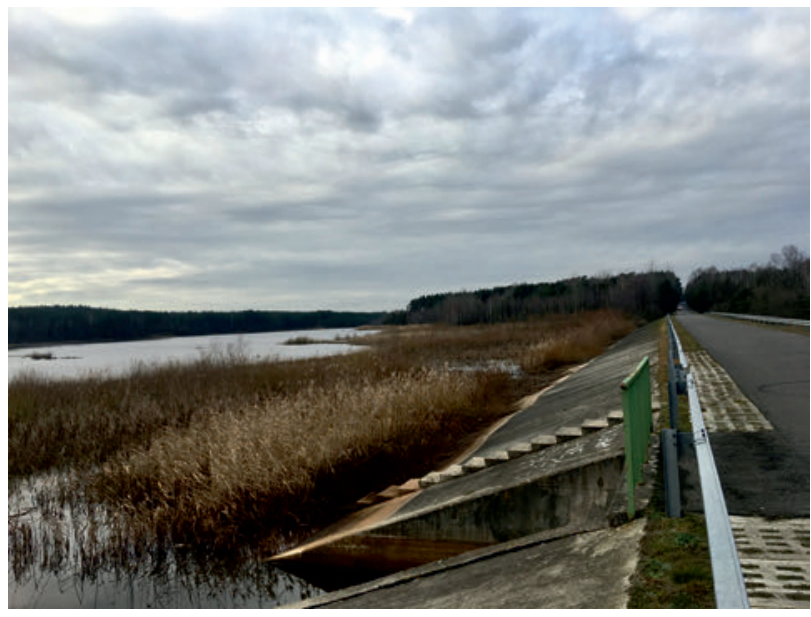

Fot. 3. Zapora boczna „Borowiec” (fot. M. Szymczyk, 05.01.2018) Photo 3. Side dam - "Borowiec" (photo by M. Szymczyk, 05.01.2018)

niebezpieczne strefy występujące w niektórych częściach akwenu. W północnej części zbiornika, w odległości około 20 metrów od brzegu, tuż pod tonią wody, skrywają się zalane pozostałości krzewów. Podczas normalnego stanu piętrzenia są one niewidoczne, tym samym stając się niebezpiecznymi dla człowieka. Podczas przygotowywania dna zbiornika nie usunięto zarośli, obcinając je na wysokości ok. 1,5 metra od powierzchni gruntu. Równie niebezpieczne są, występujące pod tonią wodną, pnie drzew w rejonie cofki zbiornika. Schowane pod wodą pozostałości pni stwarzają zagrożenie dla turystów i wędkarzy korzystających ze sprzętu pływającego. Ponadto rejon cofki jest miejscem o ograniczonej dostępności z uwagi na obecność nymfeidów i roślinności szuwarowej (fot. 4). 


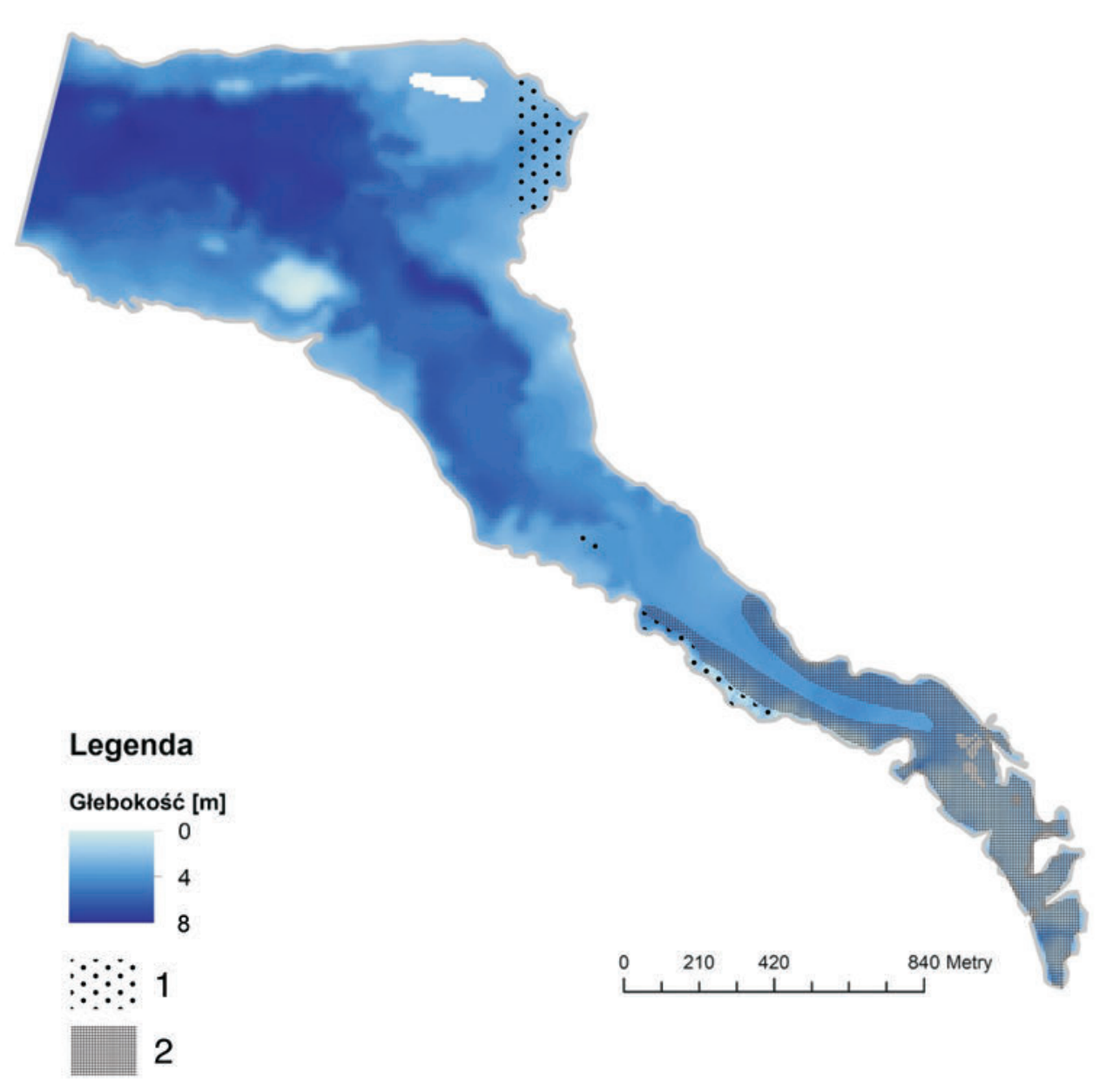

Ryc. 3. Mapa batymetryczna zbiornika Cieszanowice: 1 - pozostałości pni drzew i krzewów, 2 - strefa występowania roślinności szuwarowej i nymfeidów

Fig. 3. Bathymetric map of the Cieszanowice reservoir: 1 - remains of tree trunks and bushes, $2-$ zone of the occurrence of reed and rush communities and nympheids

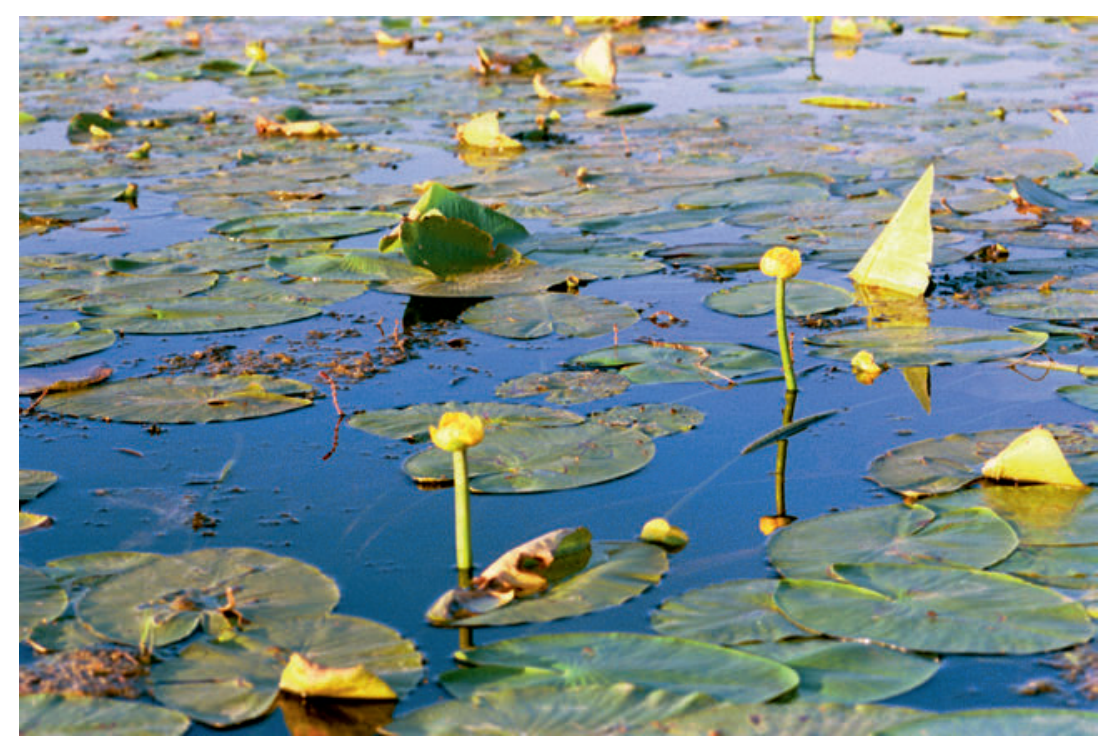

Fot. 4. Nymfeidy porastające toń wodną w rejonie cofki zbiornika Cieszanowice (fot. S. Krysiak, 03.09.2015)

Photo 4. Nympheids growing in the backwater area of the Cieszanowice reservoir (photo by S. Krysiak, 03.09.2015) 


\section{Funkcje zbiornika Cieszanowice}

W Instrukcji gospodarowania wodą zbiornika wodnego Cieszanowice (2001) stwierdzono, iż do głównych zadań tego obiektu należy:

- wyrównywanie przepływów rzeki Luciąży dla zlikwidowania deficytów wody występujących u użytkowników zaopatrujących się z rzeki Luciąży poniżej zbiornika;

- pokrycie deficytu wody na obszarze znajdującym się pod wpływem leja depresji bełchatowskiej kopalni węgla brunatnego;

- obniżenie kulminacji fali powodziowych na rzece Luciąży;

- wykorzystanie spiętrzenia wody dla celów energetycznych;

- wykorzystanie zbiornika dla celów rekreacyjnych.

Przed powstaniem zbiornika planowano wykorzystać zretencjonowane wody do nawodnień użytków rolnych poprzez:

- deszczownie;

- grawitacyjny system podsiąkowy na obszarze 900 hektarów;

- nawodnienia kropelkowe i podkoronowe.

Planowane nawodnienia kropelkowe miały być realizowane poprzez rurociąg przerzutowy, który miał dostarczać wodę do 200 hektarów gruntów w Niechcicach, oddalonych o około $10 \mathrm{~km}$ od zbiornika Cieszanowice.

Zakładane wcześniej funkcje jakie miał pełnić zbiornik Cieszanowice zostały mocno zweryfikowane podczas 20-letniej eksploatacji. Nie potwierdziły się prognozy Gładysza z lat 70. i 80. dotyczące możliwości oddziaływania leja depresyjnego KWB „Bełchatów”. Monitoring położenia zwierciadła wód podziemnych w strefie leja depresyjnego wykazał, że strefa oddziaływania odwodnienia podczas eksploatacji węgla w polu górniczym Bełchatów nie objęła dorzecza Luciąży w rejonie zbiornika Cieszanowice (Jończyk, Szczepański 2004; Motyka i in. 2007). Również dalekosiężne plany nawodnień pól uprawnych w Niechcicach były nad wyraz optymistyczne. Z uwagi na koszty nigdy nie zrealizowano żadnego z trzech wyżej wymienionych systemów nawodnień. W najbliższym otoczeniu zbiornika Cieszanowice postępuje zanik funkcji rolniczych, a zatem postulat zaopatrzenia rolnictwa w wodę pobliskich terenów stracił na aktualności.

Od kilku lat nie są również realizowane funkcje energetyczne z uwagi na wyłączenie z użytkowania turbiny zainstalowanej w budowli przelewowo-upustowej. Praktyka wykazała, że długotrwałe okresy bezopadowe, powodujące stany niżówkowe Luciąży, przyczyniają się do braku możliwości osiągnięcia normalnego poziomu piętrzenia wody w zbiorniku, zmniejszając tym samym potencjał energetyczny obiektu.

Rzeczywistymi funkcjami zbiornika Cieszanowice są funkcje retencyjne realizowane przez obniżanie kulminacji fal powodziowych i wyrównywanie przepływów Luciąży oraz wykorzystanie jego wód dla celów rekreacyjnych.

\section{Przemiany krajobrazu w dolinie Luciąży po utworzeniu zbiornika Cieszanowice}

Zbiornik Cieszanowice jest jednym z niewielu zbiorników retencyjnych $w$ województwie łódzkim. Duży udział powierzchni leśnych w otoczeniu wód zbiornika, urozmaicona rzeźba terenu i mozaikowaty krajobraz sprawiają, że jest to obszar bardzo atrakcyjny pod względem turystycznym. Funkcja rekreacyjna jest jednym z ważniejszych zadań pełnionych obecnie przez zbiornik.

W związku z powstaniem zbiornika retencyjnego nastąpiły istotne przekształcenia w krajobrazie doliny Luciąży i jej najbliższym otoczeniu.

Na początku lat 70. XX wieku opisywany obszar charakteryzował się typowym rolniczo-leśnym krajobrazem. W dnie doliny Luciąży występowały łąki i pastwiska, natomiast na terasie nadzalewowej i przylegających wysoczyznach dominowały grunty orne i lasy (ryc. 4).

W granicach obszaru przedstawionego na ryc. 4 dominują grunty orne zajmujące około $45 \%$ powierzchni, lasy $40 \%$ oraz tereny łąkowo-pastwiskowe o udziale przekraczającym $10 \%$.

Na zmiany użytkowania ziemi jakie nastąpiły w rejonie opisywanego obszaru wpłynęły nie tylko lokalne uwarunkowania związane z utworzeniem zbiornika retencyjnego, lecz również przemiany, które były typowe na obszarach wiejskich w Polsce po okresie transformacji ustrojowej lat 90. ubiegłego wieku. Wśród lokalnych uwarunkowań przede wszystkim wymienić należy likwidację wsi Kuźnica Żerechowska. Odpływ ludności z tej wsi był przyczyną zaniku użytkowania części gruntów rolnych. Okres powstania zbiornika zbiegł się z czasem głębokich przemian obszarów wiejskich w Polsce. Ich wyrazem było obserwowane, na niespotykaną do tej pory skalę, zjawisko odłogowania ziemi (Kurus, Podstawka-Chmielewska 2006). Obszary o niskiej produktywności biotycznej były miejscem ograniczenia lub całkowitego zaniechania działalności rolniczej. Terenami takimi były obszary występowania gleb wytworzonych na nadmiernie przepuszczalnych piaskach i żwirach lodowcowych i wodnolodowcowych, piaskach eolicznych oraz piaskach i żwirach akumulacji rzecznej (Krysiak 2011). Takie warunki siedliskowe reprezentuje przełomowy odcinek doliny Luciąży wraz z przylegającymi fragmentami wysoczyzn. Uprawa na tak ubogich glebach często nie miała uzasadnienia ekonomicznego i prowadziła do powstawania odłogów (ryc. 5). Na analizowanym obszarze proces odłogowania trwa już od wielu lat, na co wskazują odłogi o znacznym stopniu zaawansowania sukcesji wtórnej (fot. 5). W porównaniu z 1973 rokiem areał zajmowany przez użytkowanie rolnicze zmalał o około $87 \%$.

Utworzenie zbiornika Cieszanowice spowodowało, że wzrosło zainteresowanie tym obszarem jako przestrzenią rekreacyjną. Nieopłacalność produkcji rolnej sprzyjała sprzedaży gruntów dla celów wypoczynkowych. Proces ten zaznaczył się w fizjonomii krajobrazu w postaci współwystępowania działek letniskowych z ziemiami leżącymi odłogiem. Sytuacja taka jest prawidłowością obserwowaną na większości obszarów, gdzie funkcje rekreacyjne wypierają użytkowanie rolnicze (Krysiak 2010). 


\section{Legenda}

Pokrycie terenu w 1972 roku

Lasy

Grunty orne

Łaki i pastwiska

Nieużytki

Grunty podmokłe

Tereny zabudowane

Inne oznaczenia

- Rzeki

- Drogi

_ Zasięg zbiornika Cieszanowice

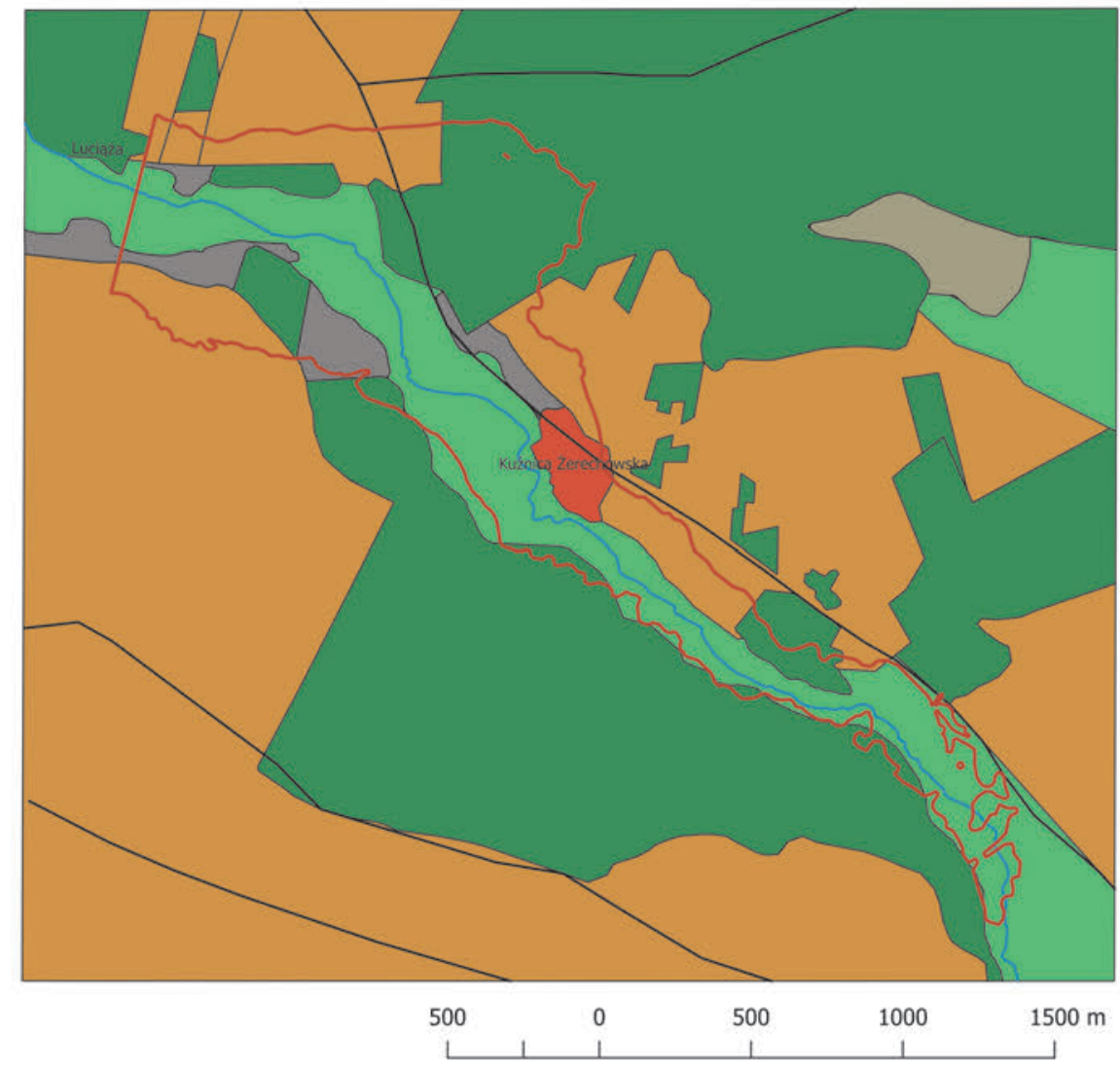

Ryc. 4. Szkic użytkowania ziemi w 1973 roku na tle granic zasięgu zbiornika Cieszanowice

Fig. 4. Sketch of land usage in 1973 in comparison with the Cieszanowice reservoir limits

\section{Legenda}

Pokrycie terenu w 2018 roku

$\square$ Lasy

Użytki rolne - grunty orne, taki i pastwiska

$\square$ Odłogi

Odłogi z zaawansowaną sukcesją wtórną

Grunty podmokłe

Zarastające żwirownie

Żwirownie i piaskownie

$\square$ Tama

Wody powierzchniowe

Tereny zabudowane

Tereny zabudowy letniskowej

$\square$ Nieużytkowana zabudowa letniskowa

Wodomistrzówka

Inne oznaczenia

-Rzeki

-Drogi

- Miejscowości

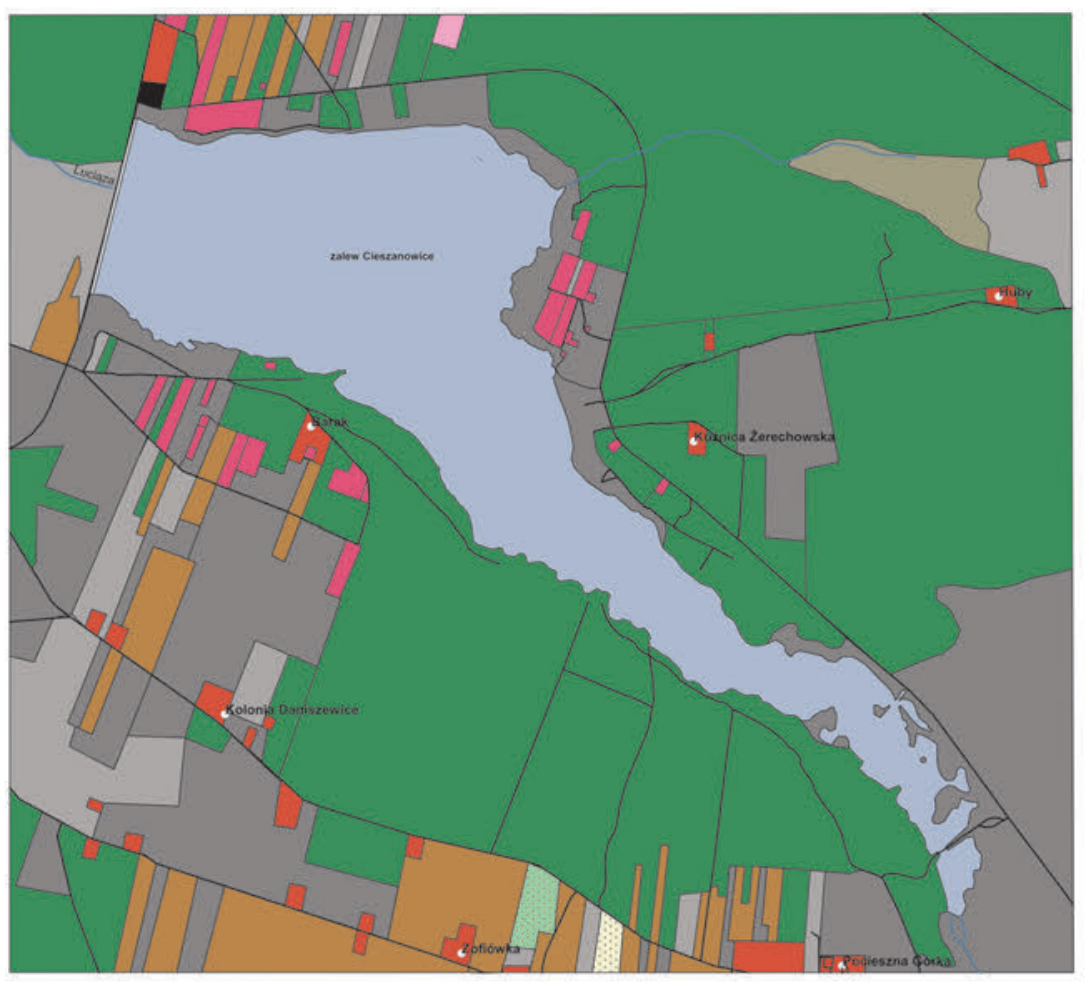

500

0

500 $1000 \mathrm{~m}$

Ryc. 5. Formy pokrycia terenu w okolicach zbiornika Cieszanowice w 2018 roku

Fig. 5. Forms of land cover in the surrounding area of the Cieszanowice reservoir in 2018 


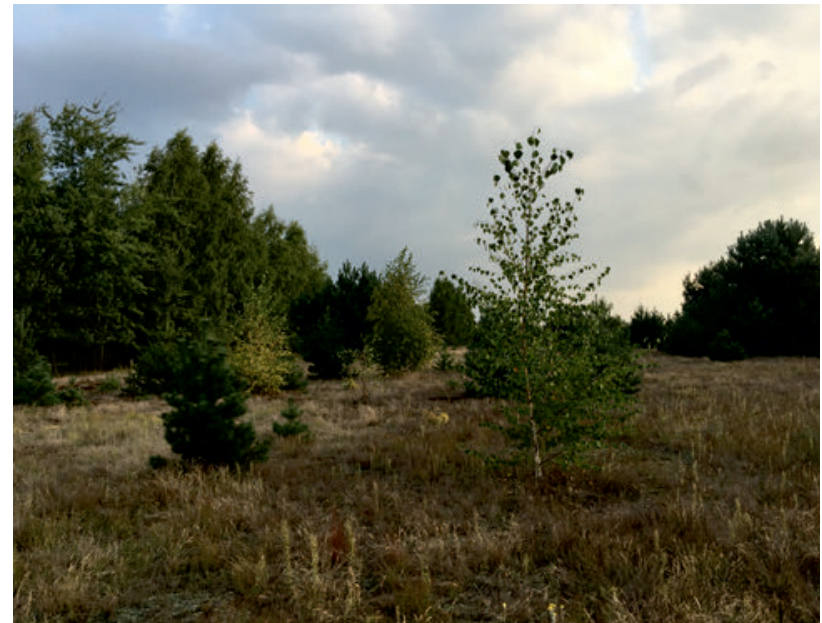

W odniesieniu do terenów otaczających zbiornik można powiedzieć, że stały się one miejscem kolonizacji turystycznej, definiowanej przez Liszewskiego (1995) jako proces trwałego zajmowania i zagospodarowywania nowych ziem przez obiekty turystyczne.
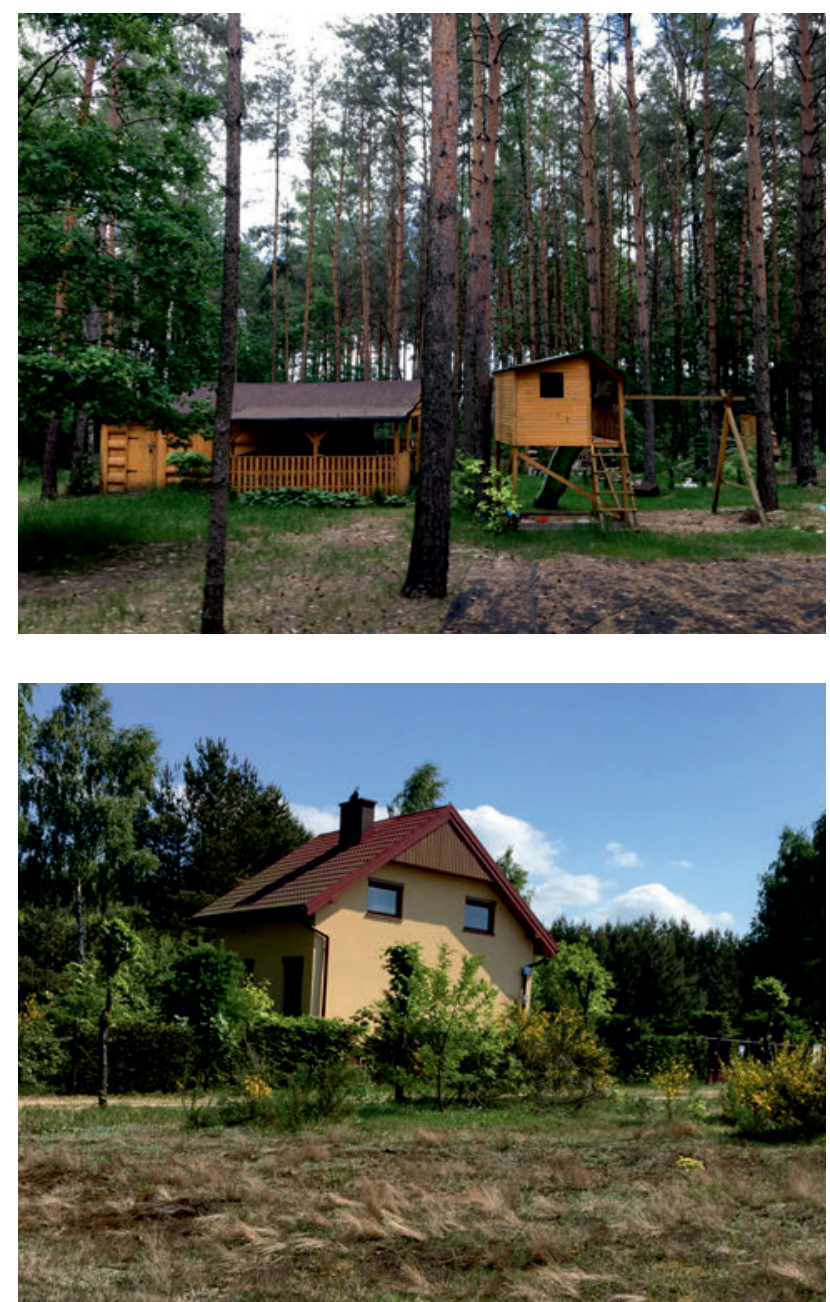

Fot. 5. Wieloletnie odłogi na nieużytkowanych gruntach rolnych w strefie brzegowej zbiornika Cieszanowice (fot. M. Szymczyk, 04.09.2018)

Photo 5. Perennial fallow strips in non-used agricultural lands in the coastal zone of the Cieszanowice reservoir (photo by M. Szymczyk, 04.09.2018)

Wraz z budową akwenu, pojawiły się różnorodne formy zabudowy letniskowej, reprezentowane przez obiekty stałe oraz sezonowe. Obiektami stałymi są najczęściej całoroczne domy mieszkalne, tzw. drugie domy. Natomiast obiektami sezonowymi są budowle nieprzystosowane do zamieszkania w okresie zimowym, takie jak przyczepy kempingowe, altany, baraki, drewniane domki letniskowe, tworzące czasami zwarte osiedla (fot. 6).
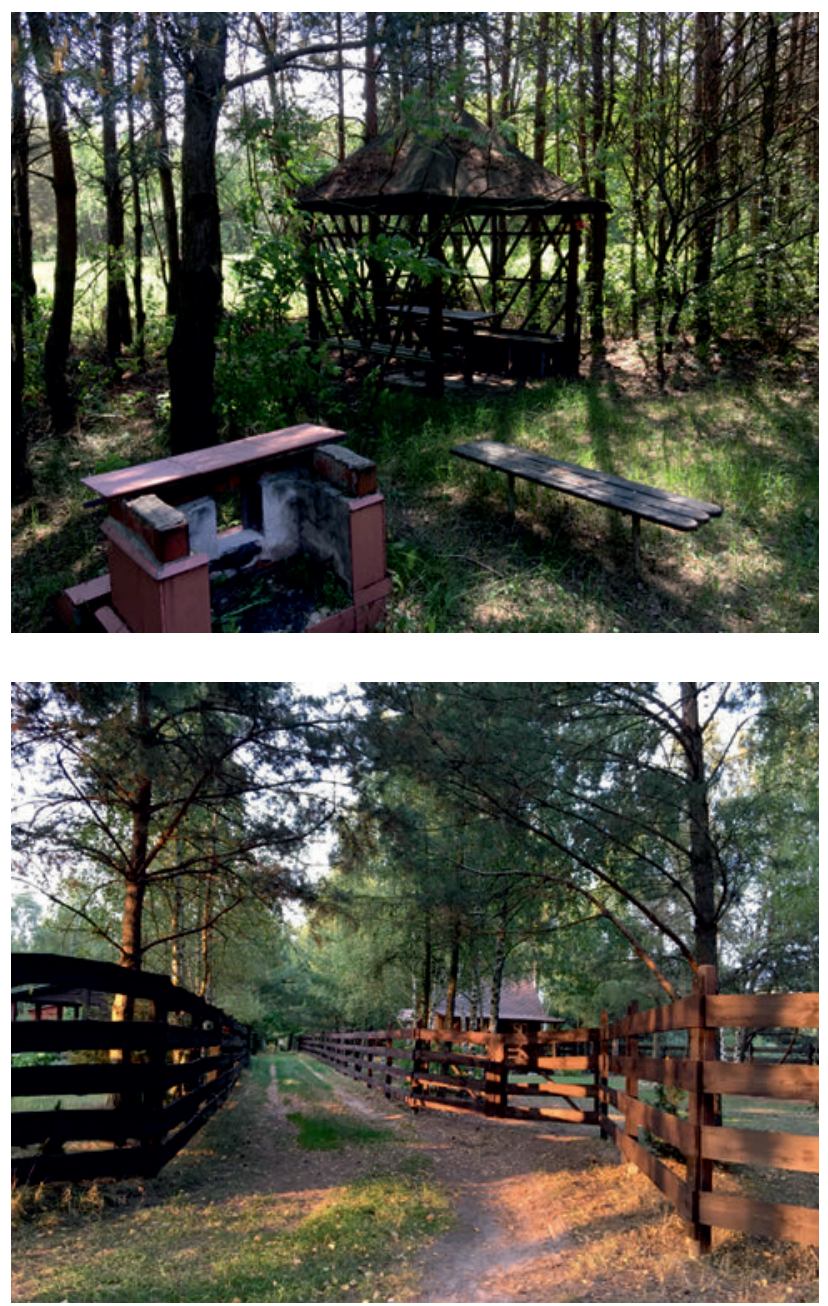

Fot. 6. Przykłady form osadnictwa turystycznego w strefie brzegowej zbiornika Cieszanowice (fot. M. Szymczyk 2018) Photo 6. Examples of tourist settlement in the coastal zone of the Cieszanowice reservoir (photo by M. Szymczyk 2018) 
Zmiany w pokryciu terenu, związane z zagospodarowaniem turystycznym, szczególnie wyraziście zaznaczyły się w strefie brzegowej zbiornika. Bardzo atrakcyjne dla osadnictwa letniskowego były powierzchnie terasowe i wysoczyznowe sąsiadujące $z$ akwenem. Zmiany w użytkowaniu nie objęły jedynie fragmentu południowej części tej strefy, pozostającej w granicach Lasów Państwowych Nadleśnictwa Piotrków. Dla zilustrowania skali przemian zestawiono mapy pokrycia terenu z 1973 i 2018 roku dla 300 metrowego pasa buforowego od brzegów akwenu (ryc. 6A, 6B). Pas ten wraz z wodami zbiornika obejmuje powierzchnię $11 \mathrm{~km}^{2}$.
Ze szkicu użytkowania ziemi w 1972 roku wynika, że lasy, pola uprawne oraz łąki były dominującymi formami użytkowania ziemi. Lasy zajmowały $37 \%$, grunty orne $36 \%$ oraz łąki $20 \%$ powierzchni obszaru. Obecnie krajobraz w pasie przyległym do zbiornika jest zdominowany przez lasy zajmujące $55,9 \%$ oraz odłogi w różnych etapach rozwoju sukcesji, których udział kształtuje się na poziomie $35,4 \%$. Pozostałą część pokrycia terenu stanowią obszary użytków rolnych $(4,6 \%)$ i osadnictwa turystycznego $(4,1 \%)$, zlokalizowanego zarówno na gruntach porolnych, jak i na terenach lasów prywatnych. Fizjonomia strefy brzegowej jest bardzo atrakcyjna. Urozmaicona rzeźba, znaczny udział lasów i odłogów, działek letniskowych tworzy interesującą mozaikę krajobrazową.
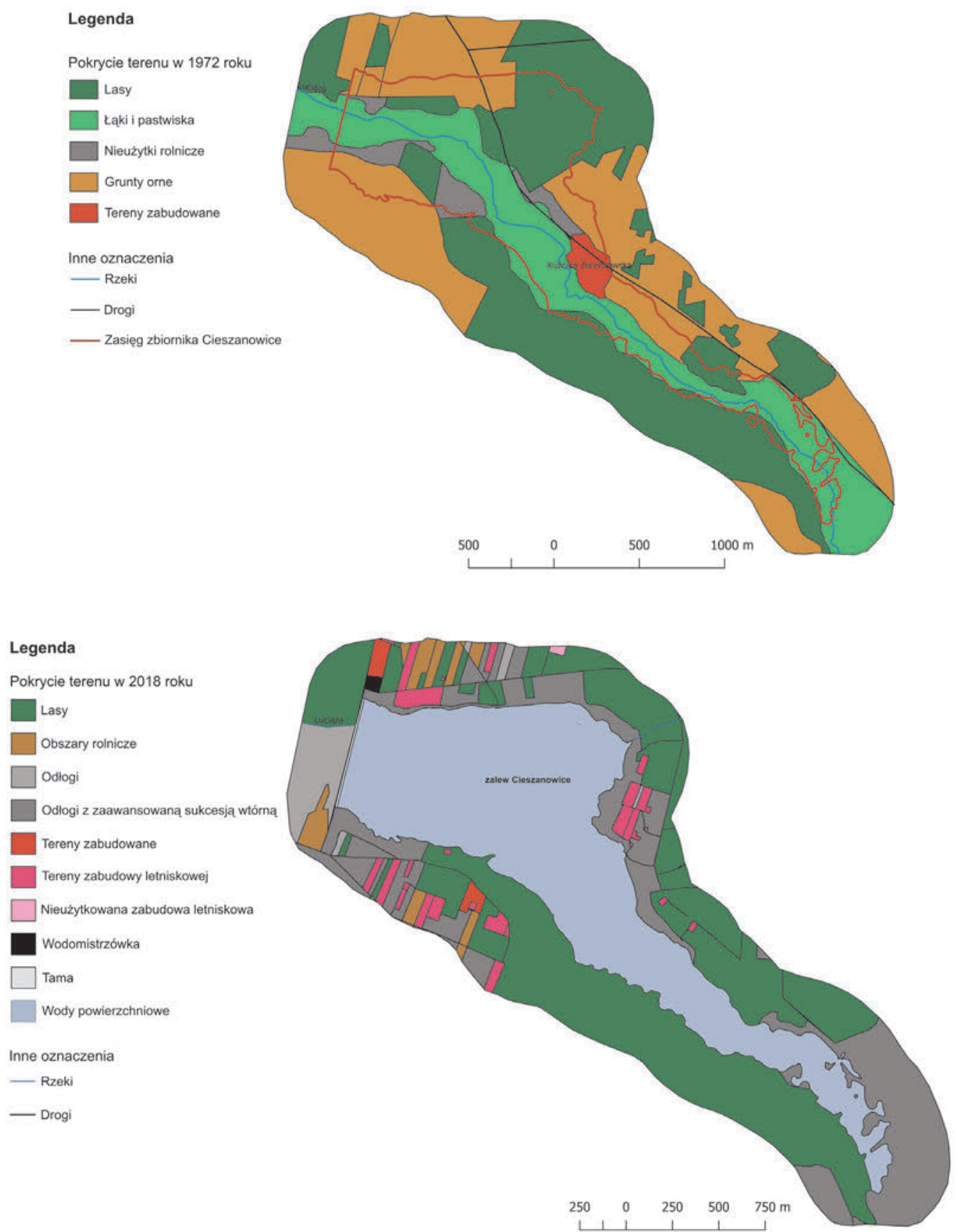

Ryc. 6. Mapy pokrycia terenu w 300-metrowym pasie od brzegów zbiornika dla 1973 r. (A) i 2018 r. (B)

Fig. 6. Maps of land cover within the 300-metre belt surrounding the reservoir in 1973 (A) and 2018 (B) 


\section{Wzrost znaczenia zbiornika Cieszanowice jako akwenu rekreacyjnego}

Zbiornik wodny Cieszanowice od początku powstania cieszy się popularnością wśród mieszkańców powiatu piotrkowskiego, radomszczańskiego oraz bełchatowskiego. Taki stan rzeczy wynika z faktu, iż w powiatach tych nie było akwenu o podobnych walorach turystyczno-rekreacyjnych. Wędkarze korzystają z wód zbiornika w ciągu całego roku, natomiast intensywne użytkowanie rekreacyjne obserwuje się w okresie wakacyjnym. Do niedawna w regionie łódzkim taką rolę spełniał zalew Sulejowski. W wyniku postępującej eutrofizacji wód, przejawiającej się rozwojem toksycznych zakwitów sinicowych w miesiącach letnich, jego znaczenie rekreacyjne drastycznie zmalało. $Z$ racji wielkości akwenu korzystają z niego jeszcze żeglarze i motorowodniacy, lecz przestał być obszarem użytkowanym przez szerokie rzesze miłośników kąpieli i odpoczynku nad wodą.

W przeciwieństwie do zalewu Sulejowskiego, zbiornik na Luciąży nigdy nie posiadał odpowiedniego zaplecza gastronomicznego, hotelowego, pól namiotowych, campingowych, infrastruktury rekreacyjnej (np. boisk, kortów tenisowych) oraz sanitarnej. W pewnym stopniu rolę tę spełnia, położony na wschodnim brzegu, bar „Przystań”, mający w swej ofercie, oprócz dań obiadowych i produktów typu fast-food, wypożyczalnię sprzętu wodnego oraz niewielkie pole namiotowe wraz z domkami o niskim standardzie. W upalne dni, w miejscach plażowania turystów, otwierane są „budki” m.in. z lodami i napojami. Latem nad „Cieszanowicami” nie brakuje amatorów sportów wodnych oraz plażowiczów. W weekendy normalnym widokiem są całe rodziny przesiadujące nad brzegami zbiornika oraz na „dziko” biwakujący turyści. Miejscami można dostrzec przyczepy kempingowe, namioty, gdzie wypoczywający zatrzymują się na kilka dni.

„Cieszanowice" są miejscem popularnym do wypoczynku w upalne lato, gdyż zbiornik oferuje duże piaszczyste plaże. Wielkość oraz ilość plaż jest uzależniona od stanu piętrzenia na zaporze. Gdy średni stan piętrzenia wody w okresie letnim nie przekracza rzędnej 204 m n.p.m. zbiornik oferuje liczne plaże o szerokości od kilku do kilkudziesięciu metrów.

\section{Wnioski}

1. Przełomowy odcinek doliny Luciąży był idealnym miejscem do lokalizacji zapory czołowej i retencjonowania wód. Zbiornik znajduje się w miejscu dawnych spiętrzeń wody wykorzystywanej do napędu młynów.

2. Z licznych funkcji, które miał pełnić zbiornik Cieszanowice realizowane są jedynie funkcje przeciwpowodziowe i rekreacyjne. Brak staranności podczas karczowania w rejonie planowanego zalewu spowodował występowanie stref zagrażających bezpieczeństwu osób korzystających ze sprzętu pływającego.

3. Powstanie zbiornika Cieszanowice spowodowało głębokie przeobrażenia w krajobrazie doliny Luciąży i jej najbliższym otoczeniu. Przede wszystkim wyrażają się one w postępującym zaniku funkcji rolniczych na rzecz funkcji rekreacyjnych. Zanikowi funkcji rolniczych na opisywanym obszarze sprzyjał znaczny udział gruntów o niskiej produktywności biotycznej oraz likwidacja wsi Kuźnica Żerechowska. Fizjonomicznym wyrazem tych przemian jest znaczny udział gruntów leżących odłogiem oraz terenów z różnorodną zabudową letniskową. Osadnictwo rekreacyjne przede wszystkim reprezentują działki z altankami, przyczepami kempingowymi, barakami, drewnianymi domkami letniskowymi. Rzadziej spotyka się całoroczne domy mieszkalne oraz tzw. drugie domy.

4. Terenem najistotniejszych przemian $w$ krajobrazie jest strefa brzegowa zbiornika, gdzie obserwuje się koncentrację osadnictwa letniskowego oraz przekształcenia związane z realizacją różnych form aktywności rekreacyjnej. Wśród przekształceń tych wymienić należy ślady całorocznej obecności wędkarzy oraz „dziko" biwakujących turystów i plażowiczów w okresie wakacyjnym.

5. Zbiornik Cieszanowice i jego otoczenie posiada liczne walory przyrodnicze, lecz brak odpowiedniego zaplecza gastronomicznego, bazy noclegowej, pól namiotowych, campingowych, infrastruktury rekreacyjnej w postaci boisk, kortów tenisowych, ścieżek rowerowych i spacerowych oraz obiektów i urządzeń sanitarnych ogranicza możliwości rekreacyjnego wykorzystania tego terenu.

\section{Literatura}

Błaszczyk, Z., 2000. Archeologiczne Zdjęcie Polski w województwie piotrkowskim - katalog stanowisk. Piotrków Trybunalski, 1-460.

Gładysz, R., 1976. Monografia hydrologiczna dorzecza Luciąży. Streszczenia Prac Habilitacyjnych i Doktorskich 1, 17-19.

Gładysz, R., 1981. Stan i Perspektywy Gospodarki Wodnej w Dorzeczu Luciąży. Acta Universitatis Lodziensis. Folia Oeconomica 11, 47-60.

Gładysz, R., 1985. Stosunki wodne w środkowej części województwa piotrkowskiego, cz. 2: Hydrografia. Studia Regionalne 1(6), 221-251.

Instrukcja gospodarowania wodą zbiornika wodnego Cieszanowice, 2001. IMGW, Warszawa.

Jończyk, I., Szczepiński, J., 2004. Czynniki rozwoju leja depresyjnego w rejonie KWB „Bełchatów” S.A. Warsztaty Górnicze „Zagrożenia naturalne w górnictwie”, 159-168.

Kondracki, J., 2000. Geografia regionalna Polski. Wydawnictwo Naukowe PWN, Warszawa.

Krysiak, S., 2010. Transformacja krajobrazów wiejskich regionu łódzkiego pod wpływem rozwoju funkcji turystycznych. Problemy Ekologii Krajobrazu 27, 231-237.

Krysiak, S., 2011. Odłogi w krajobrazach Polski środkowej-aspekty przestrzenne, typologiczne i ekologiczne. Problemy Ekologii Krajobrazu 31, 89-96.

Krzemiński, T., Nowakowski, M., 1980. Przemiany niektórych składników środowiska geograficznego województwa piotrkowskiego w świetle źródeł kartograficznych. Studia Regionalne 4, 9-34.

Kurus, J., Podstawka-Chmielewska, E., 2006. Struktura flory po dziesięcioletnim odłogowaniu gruntu ornego na dwóch typach gleb. Acta Agrobotanica 59 (2), 365-376.

Liszewski, S., 1995. Przestrzeń turystyczna. Acta Universitatis Lodziensis, Turyzm 5(2), 87-103.

Majchrowska, A., Papińska, E., 2018. Weryfikacja i uszczegółowienie granic mezoregionów fizycznogeograficznych województwa łódzkiego na podstawie danych przestrzennych. Prace i Studia Regionalne $63(1), 93-107$.

Motyka, J., Czop, M., Jończyk, W., Stachowicz, Z., Jończyk, I., Martyniak, E., 2007. Wpływ głębokiej eksploatacji węgla brunatnego na zmiany środowiska wodnego w rejonie kopalni „Bełchatów”. Górnictwo i Geoinżynieria 33 (2), 477-487.

Ocena stanu technicznego i bezpieczeństwa Zbiornika Cieszanowice, 2001. IMGW, Ośrodek Technicznej Kontroli Zapór.

Wachecka-Kotkowska, L., 2004. Ewolucja doliny Luciąży - uwarunkowania klimatyczne i lokalne. Acta Geographica Lodziensia 86, 161. 